\title{
Economic growth and financial development in Brazil: a flexible regression model approach
}

Filipe de Morais Cangussu Pessoa, Marcelo José Braga and Gabriel Alves de Sampaio Morais

\begin{abstract}
This paper examines the relationship between economic growth and financial development in Brazil. To this end, a data panel is constructed of all the Brazilian states for the period 1995-2014, with appropriate control variables and proxies for economic growth and financial development. The relationship is analysed for five different indicators of financial development, with a view to capturing its different aspects. Flexible regression modelling determines the direction of this relationship, characterizing it as linear or non-linear for each financial development indicator. It is concluded that the relationship between financial development and economic growth is positive and non-linear.
\end{abstract}

\section{Keywords}

Economic growth, financial matters, banking operations, investment, economic indicators, econometric models, Brazil

\section{JEL classification}

016, C54

Authors

Filipe de Morais Cangussu Pessoa is an economist with the Administrative Office (PRAD) of the Federal Institute of Brasilia (IFB), Brazil. Email: filipe.pessoa@ifb.edu.br.

Marcelo José Braga is a professor with the Department of Rural Economics of the Federal University of Viçosa, Brazil. Email: mjbraga@ufv.br.

Gabriel Alves de Sampaio Morais is a PhD student in Applied Economics with the Department of Rural Economics of the Federal University of Viçosa, Brazil. Email: gabriel.sampaio@ufv.br. 


\section{Introduction}

The relationship between financial development and economic growth has been discussed extensively in the theoretical and empirical literature. ${ }^{1}$ The theoretical basis for this relationship dates back to the work of Schumpeter (1934) and, later, McKinnon (1973) and Shaw (1973). Schumpeter (1934) stresses the importance of financial services in promoting economic growth and highlights the circumstances in which financial institutions can actively encourage innovation to promote economic growth, by identifying and financing productive investments. McKinnon (1973) and Shaw (1973) argue that financial repression by governments -through measures such as interest-rate ceilings and channelling credit to priority non-production sectors - hinders financial development, which they consider crucial to economic growth.

According to Levine (1997), the literature on endogenous growth also highlights the importance of financial development for long-term economic growth, owing to the effects of financial systems' functions on capital accumulation and technological innovation. These functions include mobilizing savings; obtaining information about investment acquisition and resource allocation; monitoring managers and exerting corporate control; and facilitating risk management.

However, some influential economists, such as Robinson (1952) and Kuznets (1955), assert that the role of financial development has been exaggerated or that financial development is a result of the expansion of the real economy. Therefore, counter to the hypotheses of McKinnon (1973), Shaw (1973) and endogenous growth theorists, this would indicate that the causality, if it exists, runs from growth to financial development. In particular, Robinson (1952, pp. 52 and 86) argues that when income grows, the demand for financial services increases, which, in turn, has a positive effect on financial development. If all other factors remain constant, financial development follows production growth and not vice versa.

Patrick (1966) also contributed to this literature by identifying two possible patterns in the causal relationship between financial development and economic growth. The first is demand-following and assumes that the creation of modern financial institutions, their assets and liabilities, and related financial services is in response to demand for these services by investors and savers in the real economy (Patrick, 1966, p. 174). This approach assumes that the financial system can thus support and sustain the leading sectors in the process of growth. In this case, the financial system expands as a result of real economic growth. The second pattern is supply-leading, whereby the creation of financial institutions and the supply of their financial assets, liabilities, and related financial services in advance of demand for them, especially the demand of entrepreneurs in the modern, growth-inducing sectors. The supply-leading pattern has two functions: to transfer resources from traditional (non-growth) sectors to modern sectors (which generate abundant growth); and to promote and stimulate an entrepreneurial response in these modern sectors (Patrick, 1966, pp. 175-176). In addition, Gurley and Shaw (1955) and Goldsmith (1969) argue that more developed financial markets foster economic growth by mobilizing savings and facilitating investment.

Although the earlier literature underscored the importance of financial development in the economic growth process (Gurley and Shaw, 1955; Patrick, 1966; Goldsmith, 1969), there was no compelling theoretical framework until the publication of the articles by McKinnon (1973) and Shaw (1973). According to these authors, excessive government interference in the economy and central bank rules distorts financial markets, affecting decisions on savings and investments. In other words, artificially low (subsidized) interest rates depress the economy because, by not encouraging resources to be channelled into savings, they reduced investment efficiency and, ultimately, hamper economic growth in developing countries.

\footnotetext{
1 The term "financial development" refers to the ability of a financial system to reduce market frictions such as transaction and information costs, by promoting the mobilization of savings and allocation of resource, exerting corporate control and facilitating risk management and the trade of goods, services and contracts (Levine, 1997).
} 
McKinnon and Shaw propose that developing countries should focus on liberalizing financial markets by deregulating interest rates and allowing financial institutions to allocate credit based on the viability and productivity of borrowers, their businesses or projects. The authors argue that market forces must determine the interest rate in the banking sector - banks generally being the only organized financial institutions in developing countries - to ensure the efficient allocation of resources for investment and, therefore, faster economic growth.

It is thought that financial liberalization or deregulation, in the form of increasing interest rates, not only results in a more efficient allocation of resources, but also to an increase in loan funds, as it encourages households to deposit their savings with bank which, in turn, leads to greater investment and economic growth. ${ }^{2}$ McKinnon and Shaw's approach depicts a theoretical relationship between financial liberalization and economic growth and thus implicitly shows that financial development leads to economic growth, as Schumpeter (1934) does.

The emergence of endogenous growth theory in the 1980s (Romer, 1986, 1990; Lucas, 1988; Barro, 1991) revived interest in the relationship between financial development and economic growth. As a result, numerous studies attempted to explain how the functions of the financial sector can affect the rate of endogenous economic growth (Greenwood and Jovanovic, 1990; Bencivenga and Smith, 1991; Saint-Paul, 1992; King and Levine, 1993a, 1993b; Roubini and Sala-i-Martin, 1992; Pagano, 1993; Bencivenga, Smith and Starr, 1996; Blackburn and Hung, 1998; Deidda, 2006). These studies explicitly model the role of financial intermediaries -including gathering and analysing information, distributing risk and providing liquidity - , revealing that, in general, financial development promotes growth (Levine, 1997).

However, Robinson (1952), Lucas (1988), Stern (1989), Chandavarkar (1992), Stiglitz (1994) and Singh and Weisse (1998) question the importance of the financial system in promoting economic growth. In particular, Lucas $(1988$, p. 6) asserts that "the importance of financial matters is very badly over-stressed" and Chandavarkar (1992, p. 134) observes that none of the pioneers of development economics mention the financial system as a development factor. Lastly, Singh and Weisse (1998) highlight the risks of financial collapse and economic recession as a consequence of rapid deregulation of financial systems previously controlled through state mechanisms.

These theoretical discussions reveal that there is no consensus on the role of the financial sector in economic growth or on the direction of causality between the financial sector and economic growth. However, the debate over whether the financial sector drives economic growth or vice versa has significant political implications for developed and developing countries. As Levine (1998) observes, empirical evidence on the causal relationship between financial development and economic growth can help governments determine whether financial sector reforms should be prioritized. Proponents of the first of these two viewpoints (Schumpeter, 1934; Gurley and Shaw, 1955; Goldsmith, 1969; McKinnon, 1973; Shaw, 1973; Greenwood and Jovanovic, 1990; Bencivenga and Smith, 1991; King and Levine, 1993a, 1993b; Roubini and Sala-i-Martin, 1992; Pagano, 1993) suggest that government policies should be geared towards improving the financial system, since financial development has considerable causal effects on growth. In contrast, supporters of the second viewpoint (Robinson, 1952; Lucas, 1988; Stern, 1989; Chandavarkar, 1992; Stiglitz, 1994) argue that government policies to improve the financial system have limited effects on growth, as the impact of financial development on economic growth is insignificant (Xu, 2000, p. 332).

\footnotetext{
2 This view is not unanimous. According to Pagano (1993) and De Gregorio and Guidotti (1995), the effects of the real interest rate on savings are ambiguous. Savers can either decide to save more as real interest rates rise or simply reduce or maintain the amount they save since, in a context of higher interest rates, their savings yields would remain the same or increase, thereby freeing up resources for other purposes such as consumption.
} 
The divergent theoretical approaches to the relationship between finance and growth discussed above show that economists and policymakers still face a dichotomy between the supply-leading and demand-following schools of thought (Murinde, 1996; Murinde and Eng, 1994a, 1994b; Shen and others, 2001; Deidda, 2006). The contradictory results of numerous empirical studies for groups of countries and for specific countries preclude a robust conclusion and instead seem to deepen the existing dichotomy because of their ambiguity (Lawrence, 2006).

Thus, the extensive and growing body of literature on this subject can be summarized in two main trends. On one hand, some cross-cutting and panel data studies find that financial development has a positive impact on production growth, controlling for potential simultaneity biases, omitted variables and country-specific unobserved effects. On the other hand, time series studies sometimes show one-way causality running from financial development to economic growth, sometimes two-way causality and sometimes reverse causality.

Overall, the vast body of literature on the subject indicates that country-specific studies must be conducted to better understand the causal relationship between financial development and economic growth, using a diversified set of financial measures and credit policies and bearing in mind that the institutional, economic and social specificities of each country greatly influence the relationship. ${ }^{3} \mathrm{As}$ Crocco, Santos and Amaral (2009) note, little attention has been paid to studying the regional aspects of this relationship.

Empirical evidence from Brazil on the relationship between financial system development and economic growth can be found in the studies by Arraes and Teles (2000), Monte and Távora Júnior (2000), Matos (2002), Marques Jr. and Porto Jr. (2004), Rocha and Nakane (2007) and Missio, Jayme Jr. and Oliveira (2010). In general, the results of these studies reveal a positive one-way relationship between financial development and economic growth. In other words, the data support the hypothesis that the financial system induces growth in the Brazilian economy, satisfactorily resolving the dichotomy in international literature.

One aspect that is not addressed in the first studies on the impact of financial development on economic growth in Brazil is that all the aforementioned works assume a linear relationship between financial development and economic growth. However, the traditional linear specification between finance and growth implicitly assumes that this relationship remains constant at different levels of financial development. This presupposition ignores the fact that financial development entails dynamic change. As countries grow, their financial sector develops and even their financial structure can change. Patrick (1966) emphasizes in his theoretical framework that, at certain stages, economic growth is beneficial to financial development. Bencivenga, Smith and Starr (1995) maintain that, depending on the level of financial liquidity, reducing transaction costs may encourage, stunt or have no impact on economic growth. It is therefore essential to bear in mind that the roles played by the financial sector in the economy may vary according to the sector's activity and economic growth.

More recent studies have questioned the assumption of linearity and suggested that the relationship between financial development and economic growth is non-linear. These studies examine the existence of a curb on the finance-growth relationship, by applying either an exogenous threshold on an ad hoc basis, as in Rioja and Valev (2004a, 2004b), or an endogenous threshold technique, as in Deidda and Fattouh (2002). ${ }^{4}$

\footnotetext{
3 From 1965 onwards, Brazil adopted several credit policies to promote development, in conjunction with development banks. For more details, see Morais (2008) and Cintra (2009).

4 An exogenous threshold is identified through sample distribution analysis using an ex ante criterion followed by the application of the econometric model. In the case of Rioja and Valev (2004a, 2004b), the countries in the study were divided into three groups according to income level and the econometric model was then applied, including dummy variables to capture the effect of that criterion. In contrast, an endogenous threshold is one that is determined by the econometric model on the basis of statistical criteria. Thus, in Deidda and Fattouh (2002) the threshold is defined by an indicator function based on a variable that subdivides the sample. The existence of the threshold is verified through a statistical Lagrange multiplier test.
} 
The theoretical model of Hung (2009) demonstrates that financial development is capable of making loans viable for consumption and investment purposes. While investment loans promote economic growth, consumer loans have the opposite effect. Consequently, the effect of financial development on economic growth depends on the relative magnitude of these two different channels. The main result of the model reveals that the initial level of financial development plays a key role in determining the relative magnitudes of the two channels that affect economic growth, generating non-linear relationships between financial development and economic growth.

In the specific case of Brazil, the regional inequalities argument can be extended to its financial sector: as the level of financial development in Brazil varies from state to state, the effects on economic growth are different (non-linear relationship between financial development and economic growth). Ultimately, this would indicate which levels of financial development are linked to the greatest benefits in terms of economic growth.

However extensive, the aforementioned literature has significant limitations. Firstly, these studies ignore the fact that the relationship between growth and financial development changes according to the level of financial development (Hung, 2009) and the level of national economic development (Deidda and Fattouh, 2002). Secondly, studies that adopt non-linear modelling by applying quadratic methods or thresholds may ignore other possible non-linear relationships between finance and growth. For example, an asymmetric relationship between finance and growth may suggest that a well-developed financial system generates more economic growth in less developed countries or vice versa (Shen and others, 2011).

For this reason, the flexible regression model proposed by Hamilton (2001) is used in this study. The flexible regression model can be considered to be exploratory data analysis to find the functional form that best represents the inference about the conditional expectation function, on the basis of observed data. It therefore has the following advantages over the aforementioned methods: (i) it allows for testing of non-linearity; (ii) it identifies which variable contributes to the non-linearity; (iii) it determines the form of the relationship between the dependent variable and the conditional expectation function; and (iv) it does not impose an ex ante functional form: instead, the functional form is the result of a stochastic process.

A second limitation is that there is still little research, in the case of Brazil, that takes into account the regional angle of the relationship among the variables in question. ${ }^{5}$ The regional angle refers to the impact of the functioning of the financial system on economic growth in territorial subdivisions of Brazil (such as regions, states and municipalities). This is important because there are deep regional inequalities within Brazil, as is well known.

This paper therefore seeks to develop these two approaches. This article is divided into four sections, including this introduction. The methodology for addressing non-linearity between the dependent variable and the independent variables is set out in section II. The procedures adopted for empirical analysis and the data used are described in section III and the results obtained are presented and examined. The conclusions are outlined in section IV.

5 The studies by Rocha and Nakane (2007) and Missio, Jayme Jr. and Oliveira (2010) did adopt this approach. 


\section{Methodology: the flexible regression model}

To address the non-linearity between economic growth and financial development, we have applied the flexible regression model developed by Hamilton (2001), who used the concept of a random field to detect, with certainty, non-linearity in data. ${ }^{6}$ In this context, we are interested in the non-linear regression denoted by:

$$
y t=\mu\left(x_{t}\right)+\varepsilon t, \quad t=1,2, K, T
$$

where $y_{t}$ is a scalar, $x_{t}=\left[x_{i t}\right]$ is an observed vector for the $k$ explanatory variables, over time $t, \varepsilon_{t}$ is an error with mean zero and constant variance, independent of the lagged values $x_{t}$ and $y_{t}$, and $\mu\left(x_{t}\right)$ indicates the conditional expectation function $E(y / x)$. The nature of $\mu\left(x_{t}\right)$ is key for Hamilton (2001), who considers it to be:

$$
\mu\left(x_{t}\right)=\alpha 0+\alpha^{\prime} x_{t}+\lambda m\left(g \circ x_{t}\right)
$$

where $\alpha_{0}$ and $\lambda$ are scalar parameters, $\alpha=\left[\alpha_{i}\right]$ and $g=\left[g_{i}\right]$ are parameter vectors for dimension $k, m(\cdot)$ is a realization of a random field stochastic process, and indicates element-by-element multiplication. It is assumed that nature generates $m(\cdot)$ and, consequently, $\mu\left(x_{t}\right)$ before all observations and independently of them. Having established $\mu\left(x_{t}\right)$, the values for $\varepsilon_{t}$ and $x_{t}$ are generated, and $y_{t}$ is determined through equation (1).

Interpretation of the parameters of (2) is fundamental when applying the method developed by Hamilton (2001). The scalars $\lambda$ and $g_{i}, i=1,2, \ldots, k$, characterize the relationship between $m(\cdot)$ and the conditional expectation function $\mu\left(x_{1}, x_{2}, \ldots, x_{k}\right)$. Specifically, $\lambda$ is a measure of the total weight of process $m(\cdot)$ in the conditional expectation, while the magnitude of $g_{i}$ indicates the degree of non-linearity associated with the respective $x_{i}$. Therefore, if $\lambda=0$ then $m(\cdot)$ does not contribute to the determination of the conditional expectation; in this context, (1) becomes the generalized linear model. Similarly, $g_{i}=0$ implies that the conditional expectation is linear in $x_{i}$, while $g i \neq 0$ indicates a non-linear relationship in $x_{i}$. The usual interpretations are made of the other parameters, namely $\alpha_{0}$ and $\alpha_{i}$.

For any $x, m(x)$ is a realization of the random field and is distributed

$$
m(x) \sim N(0,1), E[m(x) m(z)]=H_{k}(h)
$$

where $m(z)$ is a realization of the random field to choose an arbitrary point $z$ and the covariance function given by

$$
H_{k}(h)=\left\{\begin{array}{c}
\frac{G_{k-1}(h, 1)}{G_{k_{-} 1}(0,1)} \text { se } h \leq 1, \\
0 \text { se } h>1,
\end{array}\right.
$$

where $0<h \leq r$ being a scalar and $G_{k}(h, r)=\int_{h}^{r}\left(r^{2}-z^{2}\right) \frac{k}{2} d z$ the volume of a $k$-dimensional spheroid, with $h=(1 / 2)\left[(x-z)^{\prime}(x-z)\right]^{1 / 2}$ based on the Euclidean distance.

\footnotetext{
6 The term "flexible regression" refers to the fact that the method does not impose any ex ante functional form on the relationship between the dependent variable and a particular independent variable.
} 


\section{Econometric procedures}

Neither the conditional function $\mu\left(x_{t}\right)$ nor the parameter vector $v=\left(\alpha_{0}, \alpha^{\prime}, \sigma, g^{\prime}, \lambda\right)^{\prime}$ offer any inference, as $m(\cdot)$ is latent. Hamilton proposes representing equations (1) and (2) in the form of generalized least squares (GLS) to enable division of the unobserved part $m(x)$ into residuals. Hamilton thus reformulated the model as:

$y=X \beta+u$,

where

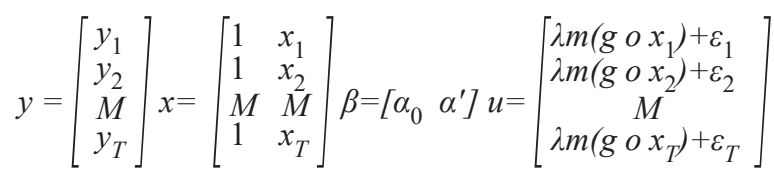

Assuming $\varepsilon_{t}$ is normal, and based on (1), (2) and (3) the result is

$$
Y \sim\left(X \beta, C+\sigma^{2} I_{T}\right),
$$

where $Y$ is a $T$-dimensional vector of observations of the dependent variable in (1), $X$ is a $T x(k+1)$ observation matrix of the $K$ explanatory variables and a column of ones associated with the intercept,

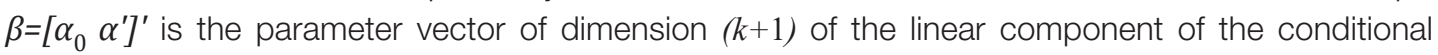
expectation, $C=\left[\lambda^{2} H_{k}\left(h_{t s}\right)\right]$ is a variance-covariance matrix of dimension $T x T$ whose typical element is given by $\lambda^{2} \operatorname{Cov}_{k}\left(m\left(g^{\circ} x_{t}\right), m\left(g \circ x_{s}\right)\right)$ and $h_{t s}$ is half the distance between $g^{\circ} x_{t}$ and $g^{\circ} x_{s}$. The log likelihood function associated with (4) is given by:

$$
\ln f\left(Y ; \beta, g, \lambda, \sigma^{2}\right)=-\frac{T}{2} \ln (2 \pi)-\frac{1}{2} \ln \left|C+\sigma^{2} I_{T}\right|-\frac{1}{2}(Y-X \beta)^{\prime}\left(C+\sigma^{2} I_{T}\right)^{-1}(Y-X \beta)
$$

Hamilton suggests using the maximum likelihood estimate (MLE) with a recursive formulation to obtain the parameters of $v$. However, to simplify the numerical optimization process, (5) can be rewritten. Conditional on an initial set of parameters, namely $\lambda$ and $g$, defining $\zeta=\lambda / \sigma, \psi=\left[\beta^{\prime} \sigma^{2}\right]^{\prime}$, as the $(k+2)$ dimensional vector of parameters for the linear part of the model, $\theta=\left[g^{\prime}, \zeta\right]^{\prime}$ as $(k+1)$ dimensional vector of the non-linear component and $W(X ; \theta)=\zeta^{2} C^{*}+I_{T}$, where $C^{*}=\lambda^{-2} C$, the right-hand side (1.9) can be rewritten as:

$$
-\frac{T}{2} \ln (2 \pi)-\frac{T}{2} \ln \sigma^{2}-\frac{1}{2} \ln |W(X ; \theta)|-\frac{1}{2 \sigma^{2}}(Y-X \beta)^{\prime} W(X ; \theta)^{-1}(Y-X \beta)
$$

The parameters of the linear part, that is to say $\beta$ and $\sigma^{2}$, which maximize (6) for a given $\theta$ can be calculated analytically as:

$$
\begin{gathered}
\tilde{\beta}(\theta)=\left[X^{\prime} W(X ; \theta)^{-1} X\right]^{-1}\left[X^{\prime} W(X ; \theta)^{-1} y\right] \\
\widetilde{\sigma}^{2}(\theta)=[y-X \widetilde{\beta}(\theta)]^{\prime} W(X ; \theta)^{-1} \frac{[y-X \tilde{\beta}(\theta)]}{T}
\end{gathered}
$$


It is therefore possible to write the concentrated log likelihood function as:

$$
\eta(\theta ; y ; X)=-\frac{T}{2} \ln (2 \pi)-\frac{T}{2} \ln \tilde{\sigma}^{2}(\theta)-\frac{1}{2} \ln |W(X ; \theta)|-\frac{T}{2}
$$

Numerical optimization of (9) provides the maximum likelihood estimate of the parameters $\left\{\hat{\alpha}_{0^{\prime}}, \hat{\alpha}^{\prime}, \hat{\sigma}^{2}, \hat{g}^{\prime}, \hat{\zeta^{\prime}}\right\}$

\section{Non-linearity test}

Given the structure of equations (1) and (2), linearity can be tested using $\lambda$ or the vector $g$, two parameters that capture linearity and curvature, respectively. If the null hypothesis $H_{0}: \lambda^{2}=0$ is not rejected, the non-linear component $\lambda m\left(g \circ x_{t}\right)$ in equation (2) disappears. Furthermore, if the null hypothesis $H_{0}: g=0$ is rejected, this indicates that the variable in question contributes non-linear proprieties to the model. Hamilton (2001) proposes a $\lambda$-test, called $\lambda \frac{H}{E}(g)$, based on the Euclidean distance measure and a Hessian information matrix. The Lagrange multiplier $(L M)$ statistic for the non-linearity test can be calculated as:

$$
\lambda_{H}^{E}(g)=\frac{\hat{u}^{\prime} H_{T} \hat{u}-\tilde{o}_{T}^{2} \operatorname{tr}\left(M_{T} H_{T} M_{T}\right)}{\left(2 \operatorname{tr}\left\{\left[M_{T} H_{T} M_{T}-(T-k-1)^{-1} M_{T} \operatorname{tr}\left(M_{T} H_{T} M_{T}\right)\right]^{2}\right\}\right) \frac{2}{T}} \sim \chi^{2}(1)
$$

where $M=I_{T}-X\left(X^{\prime} X\right)-1 X^{\prime}$.

However, the proposed $\lambda_{\bar{E}}^{H}(g)$ statistic poses a problem, since the parameter vector $g$ is not identified in the null hypothesis. To this end, Dahl and González-Rivera (2003) propose various statistical tests for non-linearity, which circumvent the problem of unidentified parameters in the null hypothesis of linearity and that are robust to the specification of the covariance function that defines the random field.

To resolve the problem of the unidentified parameter vector $g$, Dahl and González-Rivera (2003) proposed two versions of the modified $\lambda$-test, based on the Minkowski distance measure. One way of avoiding the identification problem is to fix $g$. This method assumes full knowledge of the covariance matrix, $H(g)$, associated with the random field. This version of the statistic $\lambda_{O P}^{E}$, which is based on the known covariance function, can be calculated as follows:

$$
\lambda_{O P}^{E}(g)=\frac{T^{2}}{2} \frac{k^{\prime} \tilde{x} \tilde{x} \tilde{x}^{\prime} \tilde{x} \tilde{x}^{\prime} k}{k^{\prime} k} \sim \chi^{2}(1)
$$

where $k=\operatorname{vec}\left(I_{T}-u u^{\prime} / \sigma 2\right)$.

Another approach that seeks to resolve the identification problem is to use the Taylor expansion method and auxiliary regressions to approximate the unknown covariance matrix. This version of the $\lambda$-test, denoted as $\lambda_{O P}^{A}$, is not dependent on the unidentified parameters of $g$. The statistic $\lambda_{O P}^{A}$, which is based on the unknown covariance function, can be calculated as follows:

$$
\lambda_{O P}^{A}(g)=T^{2} R^{2} \sim \chi^{2}\left(q^{*}\right)
$$

where $q^{*}=1+\sum_{j=1}^{2 k+2}\left(\frac{k+j-1}{k-1}\right)$ and $k$ indicate the number of non-linear variables. 
Another type of problem arises when $\lambda$ cannot be identified in the $H_{0}: g=0$ null hypothesis. Fixing $\lambda$, Dahl and González-Rivera (2003) propose the $g$-test, denoted as $g_{O P}$, which has the advantage of being immune to the problem of the $\lambda$ parameter in the null hypothesis. The LM statistic can be expressed as:

$$
g_{O P}=\frac{1}{2} T^{2} R^{2} \sim \chi^{2}(k)
$$

\section{Data and procedures}

To test the non-linearity model outlined in section II.2, a strategy similar to that of King and Levine (1993a), Rocha and Nakane (2007) and Missio, Jayme Jr. and Oliveira (2010) is adopted. Thus, empirical analysis will be limited to examining the impact of seven financial variables, namely: (i) government demand deposits; (ii) private sector demand deposits; (iii) fixed-term deposits; (iv) savings deposits; (v) credit transactions; (vi) discounted loans and securities; and (vii) financing. These variables are used in an effort to capture the extent to which the financial system is developed based on five indicators: market size; level of market activity (two indicators); demand deposits; and fixed-term deposits.

Specifically: (i) the proxy variable to measure market size (Mkt_size) is constructed using the ratio of liabilities (sum of demand deposits and fixed-term deposits) to the state's gross domestic product (GDP); (ii) the proxy variable to measure the first indicator of market activity (Mkt_activ1) is constructed using the ratio of financial system credit to state GDP; (iii) the proxy variable for the second indicator of market activity (Mkt_activ2) is constructed as the ratio of the sum of discounted loans and securities and financing to state GDP; (iv) the demand deposits variable (Vari_dep) is the sum of private sector demand deposits and public sector demand deposits and; finally, (v) fixed-term deposits (Fix_dep).

A strategy was therefore adopted to measure the concept of financial development using alternative methods, in order to capture as many dimensions as possible and thus increase the robustness of the tests.

The following control variables are used: the number of years of study of the population over 25 years of age as a proxy for qualification (Educ1), which is important for understanding technological development; the degree of openness of each state (calculated as the ratio of the sum of exports and imports to state GDP) (Openness) and three variables representing government expenditure in the health (Health), education (Educ2) and judicial (Judi) sectors, all defined as a proportion of state GDP.

The data for the research were obtained from the Brazilian Institute of Geography and Statistics (IBGE), the Ministry of Development, Industry and Foreign Trade (MDIC), the National Treasury (STN) and the Central Bank of Brazil (BACEN). The data are annual and cover the period 1995-2014. Table 1 summarises the data used, the period of analysis, the unit of measurement and the source of the data. All the monetary data were corrected using the Getulio Vargas Foundation's general price index (IGP-DI), with 2010 as the base year.

The analysis period was chosen in order to achieve two objectives: (i) to obtain the largest possible series of data simultaneously available for all the study's variables; and (ii) to analyse the period following the adoption of the Real Plan.

The first objective is closely linked to the quality of the estimates to be made in the study, given that the greater the number of observations, the greater the probability of obtaining desirable properties in the maximum likelihood estimator, ${ }^{7}$ such as consistency, asymptotic normality, asymptotic efficiency and invariance (Johnston and Dinardo, 1997, pp. 162-163).

7 The maximum likelihood estimator is the basis of the method to be applied in the study. 
Table 1

Description of data used to verify non-linearity between economic growth and financial development

\begin{tabular}{|c|c|c|c|}
\hline Data & Period & Unit of measurement & Source \\
\hline Government demand deposits & 1995-2014 & $\mathrm{R} \$ 1000$ from 2010 & BACEN $^{\mathrm{a}}$ \\
\hline Private sector demand deposits & 1995-2014 & $\mathrm{R} \$ 1000$ from 2010 & BACEN \\
\hline Fixed-term deposits & 1995-2014 & $\mathrm{R} \$ 1000$ from 2010 & BACEN \\
\hline Savings deposits & 1995-2014 & $\mathrm{R} \$ 1000$ from 2010 & BACEN \\
\hline Credit transactions & 1995-2014 & $\mathrm{R} \$ 1000$ from 2010 & BACEN \\
\hline Discounted loans and securities & 1995-2014 & $\mathrm{R} \$ 1000$ from 2010 & BACEN \\
\hline Financing & 1995-2014 & $\mathrm{R} \$ 1000$ from 2010 & BACEN \\
\hline State- GDP per capita & $1995-2014$ & $\mathrm{R} \$ 1000$ from 2010 & $\mathrm{IBGE}^{\mathrm{b}}$ \\
\hline State GDP & 1995-2014 & $\mathrm{R} \$ 1000$ from 2010 & IBGE \\
\hline Number of years of study of the population aged over 25 & 1995-2014 & Number of years of study (average) & IBGE \\
\hline State exports & 1995-2014 & $\mathrm{R} \$ 1000$ from 2010 & MDIC \\
\hline State imports & 1995-2014 & $\mathrm{R} \$ 1000$ from 2010 & MDIC \\
\hline Government expenditure on health & 1995-2014 & $\mathrm{R} \$ 1000$ from 2010 & STN $^{d}$ \\
\hline Government expenditure on education & 1995-2014 & $\mathrm{R} \$ 1000$ from 2010 & STN \\
\hline Government expenditure on the judiciary & 1995-2014 & $\mathrm{R} \$ 1000$ from 2010 & STN \\
\hline
\end{tabular}

Source: Prepared by the authors.

a Central Bank of Brazil.

b Brazilian Geographical and Statistical Institute.

c Ministry of Development, Industry and Foreign Trade.

d National Treasury.

Given that the central bank only began to publish agency balance sheets by municipality and state in 1995, in its Bank Statistics by Municipality (Estatística Bancária Por Município, ESTBAN), that year was chosen for the beginning of the analysis period. ${ }^{8}$ The end of the analysis period was set as 2014 , in line with the period in which data are available.

The second objective is to frame the study in a period that, according to Modenesi (2010), constitutes one of the most significant in contemporary Brazilian economic history, following five consecutive failed attempts to combat inflation that determined the direction of the country's economic policy for a decade, namely: the Cruzado Plan (1986), the Bresser Plan (1987), the Summer Plan (1989), the Collor Plan I (1990) and the Collor Plan II (1991). It was not until 1994 that the Real Plan interrupted the long process of chronic high inflation, which had intensified from the mid-1980s onwards.

This context is fundamental to studying the effects of financial development on economic growth, since the economic stability provided by the Real Plan extended the planning horizons of economic agents, by stimulating demand for financial products to make long-term investments held to maturity (Stulz, 2000).

In addition, the work of Rousseau and Wachtel (2001), which analyses the relationship between financial development and economic growth for a sample of 84 countries in the period 1960-1995, shows that there is a $13 \%$ to $25 \%$ threshold for the inflation rate, below which financial development can induce economic growth. When the inflation rate exceeds this threshold, financial development does not appear to stimulate economic growth. In contrast, this relationship becomes significantly positive when the inflation rate is between $6 \%$ and $8 \%$.

8 Between 1995 and 1999, the Central Bank of Brazil released the December balance data of each year. Monthly balances (January to December) have only been published since 2000 
Taking into account the above, and with a view to conducting an initial investigation into the relationship between economic growth and financial development and comparing estimates with the flexible regression model, the following linear panel models are estimated:

$\ln \left(\right.$ gdppercapita $\left._{i t}\right)=\alpha_{i}+\beta_{1} \ln \left(\right.$ Vari_dep $\left._{i t}\right)+\beta_{2} \ln \left(\right.$ Openess $\left._{i t}\right)+\beta_{3} \ln \left(\right.$ Educ $\left._{i t}\right)+\beta_{4} \ln \left(E d u c 2_{i t}\right)+$ $\beta_{5} \ln \left(\right.$ Health $\left._{i t}\right)+\beta_{6} \ln \left(\right.$ Judi $\left._{i t}\right)+\varepsilon_{i t}$

$\ln \left(\right.$ gdppercapita $\left._{i t}\right)=\alpha_{i}+\beta_{1} \ln \left(\right.$ Fix_dep $\left._{i t}\right)+\beta_{2} \ln \left(\right.$ Openess $\left._{i t}\right)+\beta_{3} \ln \left(\right.$ Educ $\left._{i t}\right)+\beta_{4} \ln \left(\right.$ Educ $\left._{i t}\right)+$ $\beta_{5} \ln \left(\right.$ Health $\left._{i t}\right)+\beta_{6} \ln \left(\right.$ Judi $\left._{i t}\right)+\varepsilon_{i t}$

$\ln \left(\right.$ gdppercapita $\left._{i t}\right)=\alpha_{i}+\beta_{1} \ln \left(\right.$ Mkt_size $\left._{i t}\right)+\beta_{2} \ln \left(\right.$ Openess $\left._{i t}\right)+\beta_{3} \ln \left(\right.$ Educ $\left._{i t}\right)+\beta_{4} \ln \left(\right.$ Educ $\left._{i t}\right)+$ $\beta_{5} \ln \left(\right.$ Health $\left._{i t}\right)+\beta_{6} \ln \left(\right.$ Judi $\left._{i t}\right)+\varepsilon_{i t}$

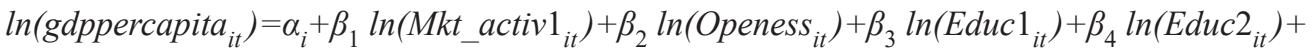
$\beta_{5} \ln \left(\right.$ Health $\left._{i t}\right)+\beta_{6} \ln \left(\right.$ Judi $\left._{i t}\right)+\varepsilon_{i t}$

$\ln \left(\right.$ gdppercapita $\left._{i t}\right)=\alpha_{i}+\beta_{1} \ln \left(\right.$ Mkt_activ $\left._{i t}\right)+\beta_{2} \ln \left(\right.$ Openess $\left._{i t}\right)+\beta_{3} \ln \left(\right.$ Educ $\left._{i t}\right)+\beta_{4} \ln \left(\right.$ Educ2 $\left._{i t}\right)+$ $\beta_{5} \ln \left(\right.$ Health $\left._{i t}\right)+\beta_{6} \ln \left(\right.$ Judi $\left._{i t}\right)+\varepsilon_{i t}$

where $\alpha_{i}$ represents the specific constant for each state, capturing the effect of the omitted variables in the model; $\beta_{1}, i=1, \ldots, 6$, are the angular coefficients of the linear part of the model and $\varepsilon_{i t}$ are the random error terms.

To further this research and analyse the relationship between economic growth and financial development, and to test whether that relationship is, in fact, linear, the following flexible regression models are estimated:

$\ln \left(\right.$ gdppercapita $\left._{i t}\right)=\alpha_{i}+\beta_{1} \ln \left(\right.$ Vari_dep $\left._{i t}\right)+\beta_{2} \ln \left(\right.$ Openess $\left._{i t}\right)+\beta_{3} \ln \left(\right.$ Educ $\left._{i t}\right)+$ $\beta_{4} \ln \left(\right.$ Educ $\left._{i t}\right)+\beta_{5} \ln \left(\right.$ Health $\left._{i t}\right)+\beta_{6} \ln \left(\right.$ Judi $\left._{i t}\right)+\hat{\sigma}_{\sigma}\left[\hat{\zeta} m\left(g_{1} \ln \left(\right.\right.\right.$ Vari_dep $\left.\left.\left._{i t}\right)\right)\right]+\varepsilon_{i t}$

$\ln \left(\right.$ gdppercapita $\left._{i t}\right)=\alpha_{i}+\beta_{1} \ln \left(\right.$ Fix_dep $\left._{i t}\right)+\beta_{2} \ln \left(\right.$ Openess $\left._{i t}\right)+\beta_{3} \ln \left(\right.$ Educ $\left._{i t}\right)+$ $\beta_{4} \ln \left(\right.$ Educ $\left._{i t}\right)+\beta_{5} \ln \left(\right.$ Health $\left._{i t}\right)+\bar{\beta}_{6} \ln \left(\right.$ Judi $\left._{i t}\right)+{ }_{\sigma}^{\wedge}\left[\hat{\zeta} m\left(g_{1} \ln \left(\right.\right.\right.$ Vari_dep $\left.\left.\left._{i t}\right)\right)\right]+\varepsilon_{i t}$

$\ln \left(\right.$ gdppercapita $\left._{i t}\right)=\alpha_{i}+\beta_{1} \ln \left(\right.$ Mkt_size $\left._{i t}\right)+\beta_{2} \ln \left(\right.$ Openess $\left._{i t}\right)+\beta_{3} \ln \left(\right.$ Educ $\left._{i t}\right)+$ $\beta_{4} \ln \left(\right.$ Educ2 $\left._{i t}\right)+\beta_{5} \ln \left(\right.$ Health $\left._{i t}\right)+\beta_{6} \ln \left(J u d i_{i t}\right)+{ }_{\sigma}^{\wedge}\left[\hat{\zeta} m\left(g_{1} \ln \left(\right.\right.\right.$ Mkt_size $\left.\left.\left._{i t}\right)\right)\right]+\varepsilon_{i t}$

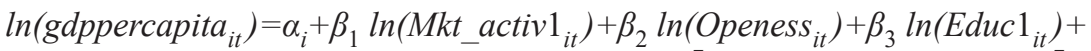
$\beta_{4} \ln \left(E d u c 2_{i t}\right)+\beta_{5} \ln \left(\right.$ Health $\left._{i t}\right)+\beta_{6} \ln \left(J u d i_{i t}\right)+{ }_{\sigma}^{\wedge}\left[\hat{\zeta} m\left(g_{1} \ln \left(\right.\right.\right.$ Activ_Merc $\left.\left.\left._{i t}\right)\right)\right]+\varepsilon_{i t}$

$\ln \left(\right.$ gdppercapita $\left._{i t}\right)=\alpha_{i}+\beta_{1} \ln \left(\right.$ Mkt_activ $\left._{i t}\right)+\beta_{2} \ln \left(\right.$ Openess $\left._{i t}\right)+\beta_{3} \ln \left(\right.$ Educ $\left._{i t}\right)+$ $\beta_{4} \ln \left(\right.$ Educ $\left._{i t}\right)+\beta_{5} \ln \left(\right.$ Health $\left._{i t}\right)+\beta_{6} \ln \left(\right.$ Judi $\left._{i t}\right)+{ }_{\sigma}^{\wedge}\left[\hat{\zeta} m\left(g_{1} \ln \left(\right.\right.\right.$ Mkt_activ $\left.\left.\left.{ }_{i t}\right)\right)\right]+\varepsilon_{i t}$

where $\alpha_{i}$ represents the specific constant for each state, capturing the effect of the omitted variables on the model, $\beta_{1}, i=1, \ldots, 6$, are the angular coefficients of the linear part of the model, $\varepsilon_{i t}$ are the random error terms, $\hat{\lambda}=\hat{\sigma} \hat{\zeta}$ and $g_{1}$ characterize the relationship between the random field and the conditional expectation function $\mu\left(x_{t}\right)$. 


\section{Results and analysis}

Map 1 provides a spatial context for the five financial development indicators used, by presenting the average values of the indicators over the 1995-2014 period, in four quartiles, for all Brazilian states.

Map 1

Brazil: geographical distribution by quartile of five financial development indicators by state

A. Demand deposits

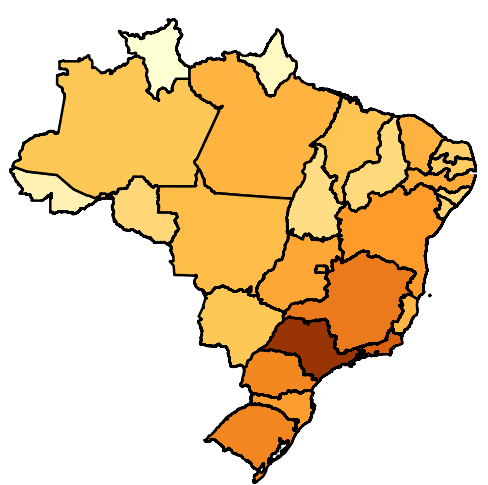

C. Market size

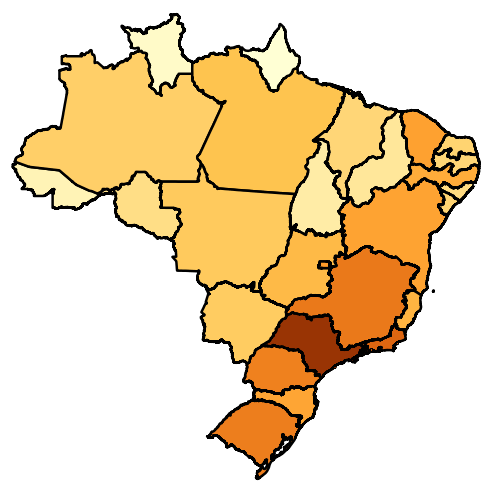

B. Fixed-term deposits

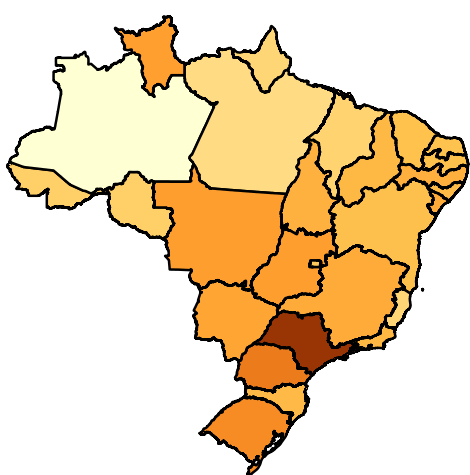

D. Market activity 1

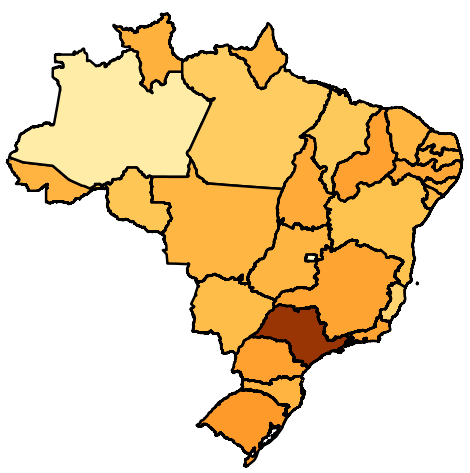

$100 \%$

$75 \%$

$50 \%$

$25 \%$

$0 \%$

E. Market activity 2

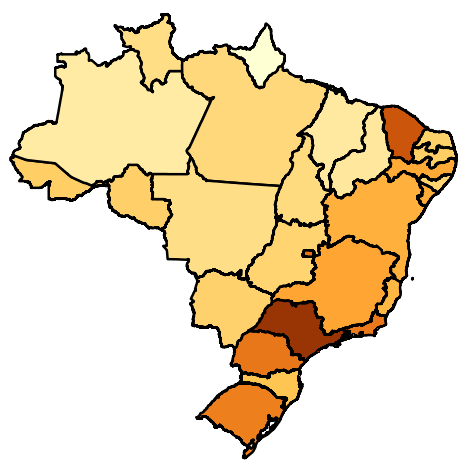

$100 \%$

$75 \%$

$50 \%$

$25 \%$

$0 \%$

Source: Prepared by the authors.

Analysis of map 1 shows that, for indicators Vari_dep and Fix_dep (see maps 1A and 1B), the states with the highest level of financial development are mainly in the South and South-East Regions. In the case of the Mkt_size indicator, the states with the greatest financial development are in the 
South, South-East and North-East Regions. Specifically, the states of Bahía, Sergipe, Pernambuco and Rio Grande do Norte, which are all in the North-East Region.

Lastly, in the case of the indicators Mkt_activ1 and Mkt_activ2, the regions with the highest levels of financial development are the South, South-East and Central-West Regions. In short, irrespective of the financial development indicator used, the states of the South and South-East Regions generally have the highest levels of financial development.

Table 2 presents the results of models (14) to (18) and of the Chow and Hausman tests to indicate whether the panel data should be viewed as pooled data against fixed effects or fixed effects against random effects.

Table 2

Linear panel models with fixed effects for five financial development indicators

\begin{tabular}{|c|c|c|c|c|c|}
\hline Variables & (1) & (2) & (3) & (4) & (5) \\
\hline Constant & $\begin{array}{r}7.5479^{\star * \star} \\
(0.0679) \\
{[0.0000]}\end{array}$ & $\begin{array}{r}7.6581^{\star \star *} \\
(0.0621) \\
{[0.0000]}\end{array}$ & $\begin{array}{r}8.2716^{\star \star *} \\
(0.0794) \\
{[0.0000]}\end{array}$ & $\begin{array}{r}8.2082^{\star * *} \\
(0.0760) \\
{[0.0000]}\end{array}$ & $\begin{array}{r}8.3855^{\star \star \star} \\
(0.0796) \\
{[0.0000]}\end{array}$ \\
\hline Vari_dep & $\begin{array}{c}0.0523^{\star \star \star} \\
(0.0043) \\
{[0.0000]}\end{array}$ & - & - & - & - \\
\hline Fix_dep & - & $\begin{array}{r}0.0472^{\star * *} \\
(0.0031) \\
{[0.0000]}\end{array}$ & - & - & - \\
\hline Mkt_size & - & - & $\begin{array}{r}0.0457^{\star * *} \\
(0.0040) \\
{[0.0000]}\end{array}$ & - & - \\
\hline Mkt_activ1 & - & - & - & $\begin{array}{r}0.0378^{\star \star \star} \\
(0.0033) \\
{[0.0000]}\end{array}$ & - \\
\hline Mkt_activ2 & - & - & - & - & $\begin{array}{r}0.0448^{\star \star \star} \\
(0.0035) \\
{[0.0000]}\end{array}$ \\
\hline Openness & $\begin{array}{c}0.0069^{\mathrm{NS}} \\
(0.0063) \\
{[0.2760]}\end{array}$ & $\begin{array}{c}0.0143^{\star \star} \\
(0.0059) \\
{[0.0160]} \\
\end{array}$ & $\begin{array}{l}0.0119^{*} \\
(0.0064) \\
{[0.0620]}\end{array}$ & $\begin{array}{c}0.0164^{\star \star} \\
(0.0064) \\
{[0.0110]}\end{array}$ & $\begin{array}{c}0.0145^{\star \star} \\
(0.0062) \\
{[0.0200]}\end{array}$ \\
\hline Educ1 & $\begin{array}{r}0.6098^{\star \star \star} \\
(0.0379) \\
{[0.0000]}\end{array}$ & $\begin{array}{r}0.5776^{\star \star \star} \\
(0.0349) \\
{[0.0000]}\end{array}$ & $\begin{array}{r}0.6854^{\star * \star} \\
(0.0353) \\
{[0.0000]}\end{array}$ & $\begin{array}{r}0.7123^{\star * *} \\
(0.0337) \\
{[0.0000]} \\
\end{array}$ & $\begin{array}{r}0.6332^{\star \star \star} \\
(0.0354) \\
{[0.0000]}\end{array}$ \\
\hline Educ2 & $\begin{array}{r}-0.0477^{\star \star \star} \\
(0.0104) \\
{[0.0000]}\end{array}$ & $\begin{array}{r}-0.05019^{\star \star \star} \\
(0.0099) \\
{[0.0000]} \\
\end{array}$ & $\begin{array}{r}-0.0512^{\star \star \star} \\
(0.0106) \\
{[0.0000]}\end{array}$ & $\begin{array}{r}-0.0561^{\star \star \star} \\
(0.0106) \\
{[0.0000]}\end{array}$ & $\begin{array}{r}-0.0476^{\star \star \star} \\
(0.0103) \\
{[0.0000]}\end{array}$ \\
\hline Health & $\begin{array}{r}0.0374^{\star \star \star} \\
(0.0090) \\
{[0.0000]}\end{array}$ & $\begin{array}{r}0.0355^{\star * \star} \\
(0.0085) \\
{[0.0000]}\end{array}$ & $\begin{array}{r}0.0369^{* * *} \\
(0.0092) \\
{[0.0000]}\end{array}$ & $\begin{array}{r}0.0447^{\star \star \star} \\
(0.0093) \\
{[0.0000]}\end{array}$ & $\begin{array}{r}0.0363^{\star * *} \\
(0.0089) \\
{[0.0000]}\end{array}$ \\
\hline Judi & $\begin{array}{r}-0.0054^{\star \star} \\
(0.0023) \\
{[0.0200]}\end{array}$ & $\begin{array}{r}-0.0058^{\star \star \star} \\
(0.0022) \\
{[0.0070]}\end{array}$ & $\begin{array}{r}-0.0052^{* *} \\
(0.0023) \\
{[0.0270]}\end{array}$ & $\begin{array}{r}-0.0059^{\star *} \\
(0.0023) \\
{[0.0120]}\end{array}$ & $\begin{array}{r}-0.0060^{\star \star *} \\
(0.0023) \\
{[0.0090]}\end{array}$ \\
\hline Chow test & {$[0.0000]^{\star \star \star}$} & {$[0.0000]^{\star \star \star}$} & {$[0.0000]^{\star \star \star}$} & {$[0.0000]^{\star \star *}$} & {$[0.0000]^{\star \star *}$} \\
\hline Hausman test & {$[0.0000]^{\star \star \star}$} & {$[0.0000]^{\star \star \star}$} & {$[0.0000]^{\star \star \star}$} & {$[0.0000]^{\star \star \star}$} & {$[0.0000]^{\star \star \star}$} \\
\hline Observations & 540 & 540 & 540 & 540 & 540 \\
\hline $\mathrm{R}^{2}$ & 0.69 & 0.70 & 0.68 & 0.68 & 0.63 \\
\hline
\end{tabular}

Source: Prepared by the authors.

Note: ${ }^{* \star \star}$ Significant at $1 \%,{ }^{* \star}$ significant at $5 \%$ and NS not significant. The values in parentheses and square brackets correspond to the standard deviation and the $p$-value, respectively. 
The results presented in table 2 indicate that the estimated panel models should consider the fixed effects transformation, since the Hausman and Chow tests were statistically significant at $1 \%$ for all the models in question.

With the exception of the variable Openness in model (14), all of the control variables were statistically significant at the commonly-used levels of significance (1\%,5\% and $10 \%)$. In addition, all of the proxy variables for financial development were positive and statistically significant at $1 \%$. Therefore, the results presented in table 2 indicate that the relationship between financial development and economic growth in Brazilian states in the period from 1994 to 2014 is positive and linear.

All the panel models were estimated using the fixed effects transformation, rather than the random effects model, to control for unobserved heterogeneity, since, according to Wooldridge (2001), in this context the sample coincides with the population and each observation for a Brazilian state, i.e. panel member, represents itself and was not sampled randomly.

Table 3 contains the results of models (19) to (23) and non-linearity tests (10), (11), (12) and (13).

Table 3

Non-linear flexible models for five financial development indicators

\begin{tabular}{|c|c|c|c|c|c|}
\hline Variables & (1) & (2) & (3) & (4) & (5) \\
\hline Constant & $\begin{array}{c}0.0176^{\mathrm{NS}} \\
(0.0209) \\
{[0.4001]}\end{array}$ & $\begin{array}{c}0.0101^{\mathrm{NS}} \\
(0.0153) \\
{[0.5095]}\end{array}$ & $\begin{array}{c}0.0113^{\mathrm{NS}} \\
(0.0238) \\
{[0.6351]}\end{array}$ & $\begin{array}{r}-0.0044^{\mathrm{NS}} \\
(0.0218) \\
{[0.8401]}\end{array}$ & $\begin{array}{c}0.0053^{\mathrm{NS}} \\
(0.0206) \\
{[0.7971]}\end{array}$ \\
\hline Vari_dep & $\begin{array}{c}0.0680^{\star \star \star} \\
(0.0132) \\
{[0.0000]}\end{array}$ & - & - & - & - \\
\hline Fix_dep & - & $\begin{array}{r}0.0433^{\star \star \star} \\
(0.0081) \\
{[0.0000]}\end{array}$ & - & - & - \\
\hline Mkt_size & - & - & $\begin{array}{c}0.0413^{\star \star \star} \\
(0.0147) \\
{[0.0051]}\end{array}$ & - & - \\
\hline Mkt_activ1 & - & - & - & $\begin{array}{c}0.0322^{\star \star \star} \\
(0.0126) \\
{[0.0109]}\end{array}$ & - \\
\hline Mkt_activ2 & - & - & - & - & $\begin{array}{c}0.0464^{\star \star \star} \\
(0.0106) \\
{[0.0000]}\end{array}$ \\
\hline Openness & $\begin{array}{l}0.0099 * \\
(0.0059) \\
{[0.0939]}\end{array}$ & $\begin{array}{r}0.0157^{\star \star \star} \\
(0.0056) \\
{[0.0052]}\end{array}$ & $\begin{array}{c}0.0159^{\star \star \star} \\
(0.0062) \\
{[0.0106]}\end{array}$ & $\begin{array}{c}0.0185^{\star \star \star} \\
(0.0061) \\
{[0.0025]}\end{array}$ & $\begin{array}{c}0.0183^{\star \star \star} \\
(0.0058) \\
{[0.0017]}\end{array}$ \\
\hline Educ1 & $\begin{array}{c}0.4422^{\star \star \star} \\
(0.0414) \\
{[0.0000]}\end{array}$ & $\begin{array}{r}0.4780^{\star \star \star} \\
(0.0346) \\
{[0.0001]}\end{array}$ & $\begin{array}{r}0.6308^{\star \star \star} \\
(0.0358) \\
{[0.0000]}\end{array}$ & $\begin{array}{r}0.7076^{\star \star \star} \\
(0.0320) \\
{[0.0000]}\end{array}$ & $\begin{array}{r}0.5375^{\star \star \star} \\
(0.0372) \\
{[0.0000]}\end{array}$ \\
\hline Educ2 & $\begin{array}{r}-0.0439^{\star \star \star} \\
(0.0093) \\
{[0.0000]}\end{array}$ & $\begin{array}{r}-0.0503^{\star \star \star} \\
(0.0090) \\
{[0.0000]}\end{array}$ & $\begin{array}{r}-0.0525^{\star \star \star} \\
(0.0101) \\
{[0.0000]}\end{array}$ & $\begin{array}{r}-0.0632^{\star \star \star} \\
(0.0102) \\
{[0.0000]}\end{array}$ & $\begin{array}{r}-0.0507^{\star * *} \\
(0.0098) \\
{[0.0000]}\end{array}$ \\
\hline Health & $\begin{array}{r}0.0304^{\star \star \star} \\
(0.0081) \\
{[0.0002]} \\
\end{array}$ & $\begin{array}{r}0.0303^{\star \star \star} \\
(0.0078) \\
{[0.0001]} \\
\end{array}$ & $\begin{array}{r}0.0371^{\star \star \star} \\
(0.0087) \\
{[0.0000]}\end{array}$ & $\begin{array}{r}0.0495^{\star \star \star} \\
(0.0089) \\
{[0.0000]}\end{array}$ & $\begin{array}{r}0.0395^{\star \star \star} \\
(0.0087) \\
{[0.0000]}\end{array}$ \\
\hline Judi & $\begin{array}{r}-0.0041^{\star \star} \\
(0.0021) \\
{[0.0514]}\end{array}$ & $\begin{array}{r}-0.0038^{\star \star} \\
(0.0020) \\
{[0.0580]}\end{array}$ & $\begin{array}{r}-0.0050^{\star \star} \\
(0.0022) \\
{[0.0234]}\end{array}$ & $\begin{array}{r}-0.0054^{\star \star \star} \\
(0.0022) \\
{[0.0144]}\end{array}$ & $\begin{array}{r}-0.0054^{\star \star \star} \\
(0.0021) \\
{[0.0104]}\end{array}$ \\
\hline & $\begin{array}{r}0.0601^{\star \star *} \\
(0.0019) \\
{[0.0000]}\end{array}$ & $\begin{array}{r}0.0575^{\star \star \star} \\
(0.0018) \\
{[0.0000]} \\
\end{array}$ & $\begin{array}{r}0.0652^{\star \star \star} \\
(0.0020) \\
{[0.0000]}\end{array}$ & $\begin{array}{r}0.0651^{\star \star \star} \\
(0.0021) \\
{[0.0000]}\end{array}$ & $\begin{array}{r}0.0622^{\star \star \star} \\
(0.0019) \\
{[0.0000]}\end{array}$ \\
\hline & $\begin{array}{c}0.5038^{\star * \star} \\
(0.0926) \\
{[0.0000]}\end{array}$ & $\begin{array}{r}-0.5761^{\star \star *} \\
(0.1526) \\
{[0.0002]}\end{array}$ & $\begin{array}{c}0.5001^{\star \star \star} \\
(0.1587) \\
{[0.0017]}\end{array}$ & $\begin{array}{c}0.5003^{\star *} \\
(0.2240) \\
{[0.0259]}\end{array}$ & $\begin{array}{c}0.5020^{\star \star *} \\
(0.1340) \\
{[0.0002]}\end{array}$ \\
\hline Vari_dep (g1) & $\begin{array}{c}0.9664^{\star \star \star} \\
(0.2170) \\
{[0.0000]}\end{array}$ & - & - & - & - \\
\hline Fix_dep (g1) & - & $\begin{array}{r}2.1403 \\
(0.0710) \\
{[0.0000]}\end{array}$ & - & - & - \\
\hline
\end{tabular}


Table 3 (concluded)

\begin{tabular}{|c|c|c|c|c|c|}
\hline Variables & (1) & (2) & (3) & (4) & (5) \\
\hline Mkt_size (g1) & - & - & $\begin{array}{r}1.0182^{\star * *} \\
(0.0081) \\
{[0.0000]}\end{array}$ & - & - \\
\hline Mkt_activ1 (g1) & - & - & - & $\begin{array}{c}0.9025^{\star \star} \\
(0.0169) \\
{[0.0000]}\end{array}$ & - \\
\hline Mkt_activ2 (g1) & - & - & - & - & $\begin{array}{r}0.8470^{\star \star \star} \\
(0.0144) \\
{[0.0000]}\end{array}$ \\
\hline $\log L$ & 743.65900 & 759.17876 & 699.53436 & 699.81553 & 724.35636 \\
\hline$\lambda_{H}^{E}$-test & {$[0.001]^{\star \star \star}$} & {$[0.001]^{\star \star \star}$} & {$[0.001]^{\star \star \star}$} & {$[0.011]^{\star \star \star}$} & {$[0.001]^{\star \star \star}$} \\
\hline$\lambda_{O P}^{E}$-test & {$[0.001]^{\star \star \star}$} & {$[0.001]^{\star \star \star}$} & {$[0.001]^{\star \star \star}$} & {$[0.017]^{\star \star \star}$} & {$[0.001]^{\star \star \star}$} \\
\hline$\lambda_{O P}^{A}$-test & {$[0.001]^{* \star *}$} & {$[0.001]^{\star * *}$} & {$[0.001]^{\star \star *}$} & {$[0.900]^{\mathrm{NS}}$} & {$[0.001]^{\star \star \star}$} \\
\hline$g_{O P}$-test & {$[0.001]^{\star \star \star}$} & {$[0.001]^{\star \star \star}$} & {$[0.001]^{\star \star \star}$} & {$[0.982]^{\mathrm{NS}}$} & {$[0.001]^{\star \star \star}$} \\
\hline
\end{tabular}

Source: Prepared by the authors.

Note: $\quad{ }^{* \star *}$ Significant at $1 \%,{ }^{* \star}$ significant at $5 \%$ and NS not significant. The values in parentheses and square brackets correspond to the standard deviation and the $\mathrm{p}$-value, respectively.

In models (1), (2), (3), (4) and (5) of table 3, the financial development indicators for which are, respectively, Vari_dep, Fix_dep, Mkt_size, Mkt_activ1 and Mkt_activ2, all variables were statistically significant at the commonly-used levels of significance (1\%, 5\% and $10 \%)$.

For the control variables, these models indicate a direct relationship between the explanatory variables Openness, Educ1 and Health and the dependent variable of state GDP per capita. In the case of the control variables Educ2 and Judi, the opposite occurs.

For the financial development indicators, the five models presented a positive relationship with state GDP per capita, as evidenced by the signs of the coefficients of the linear part of Vari_dep, Fix_dep, Mkt_size, Mkt_activ1 and Mkt_activ2.

The parameters $\sigma, \zeta$ and $g 1$, which capture the part of the non-linear relationship between the financial development indicators and state GDP per capita, were statistically significant at $1 \%$ and $5 \%$ (in the case of model (4) for the $\zeta$ coefficient).

Given that the tests $\lambda_{H}^{E}, \lambda_{O P}^{E}, \lambda_{O P}^{A}$ and $g_{O P}$ were significant at $1 \%$ for models (1), (2), (3) and (5), it can be inferred that there is a non-linear relationship between Vari_dep, Fix_dep, Mkt_size and Mkt_activ2 and state GDP per capita. The $\lambda_{O P}^{A}$ and $g_{O P}$ tests for model (4) are the exception, as they were not statistically significant, even at $10 \%$. However, all of the other tests were significant at $1 \%{ }^{9}$

In light of the results presented in table 3 , a researcher who had considered the results obtained in table 1 to be valid, would have been led into error, as it would be assumed that relationship between economic growth and financial development was linear, when in fact it is not for any of the five indicators analysed.

Non-linearity tests only tell part of the story, since they are tests in which the null hypothesis assumes a linear relationship between the dependent variable and the independent variable being considered. Thus, rejection of the null hypothesis under these tests means that this relationship can take any form (non-linear), except linear.

Thus, one question that has not yet been answered is: what is the precise form of the relationship between the five financial development indicators and state GDP per capita? Figure 1 attempts to answer this question, by plotting state GDP per capita against the five financial development indicators.

9 As the empirical example put forward by Dahl and González-Rivera (2003) shows, when two or more tests indicate rejection of the linearity null hypothesis, the model is considered to be non-linear. 
Figure 1

Non-linear relationship between per capita GDP and five financial development variables

A. Demand deposits

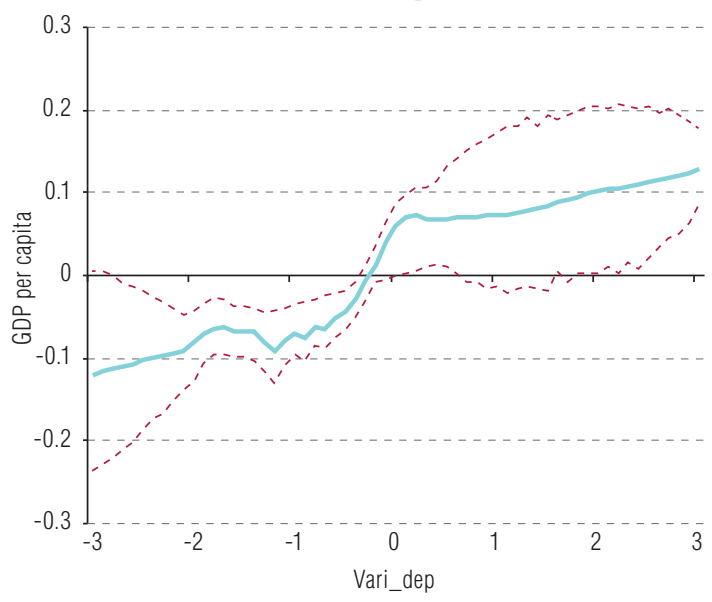

C. Market size

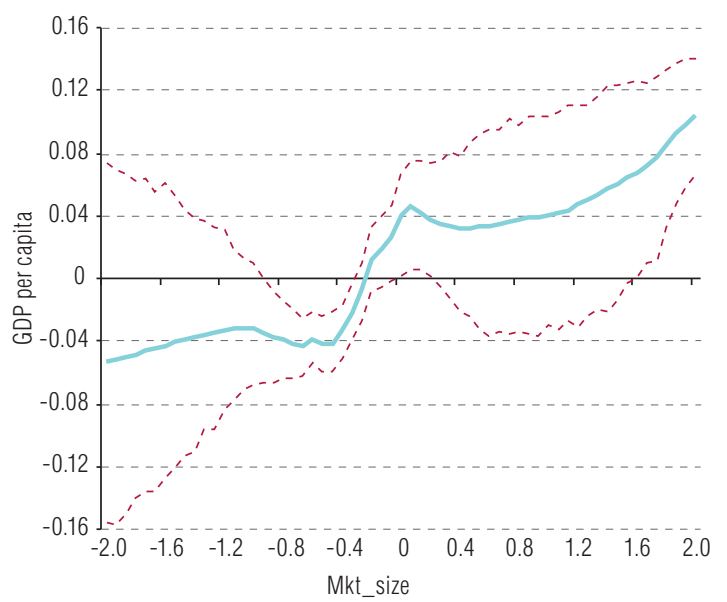

B. Fixed-term deposits

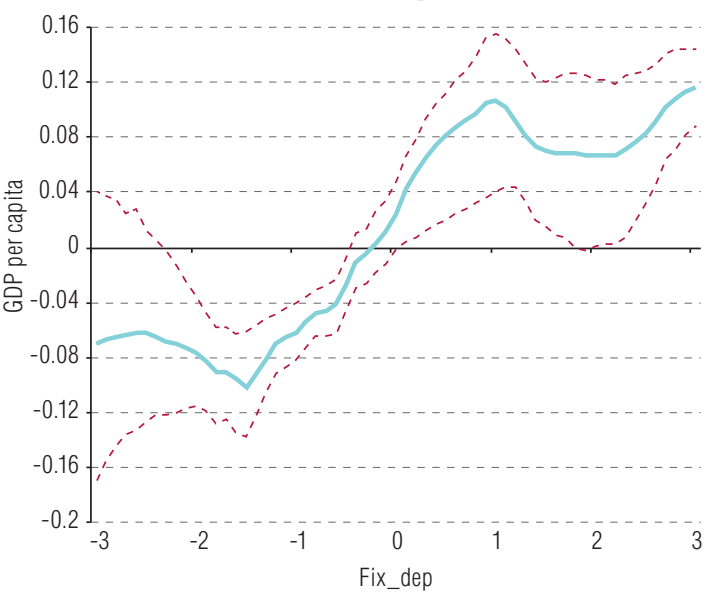

D. Market activity 1

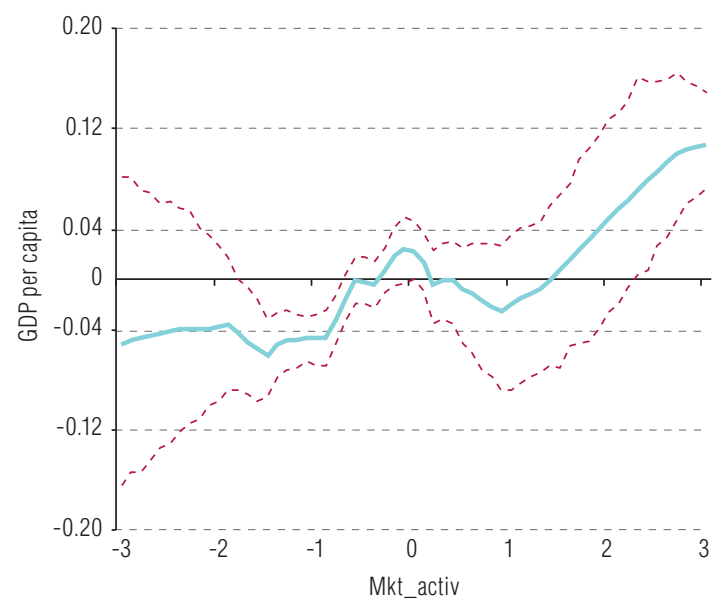

E. Market activity 2

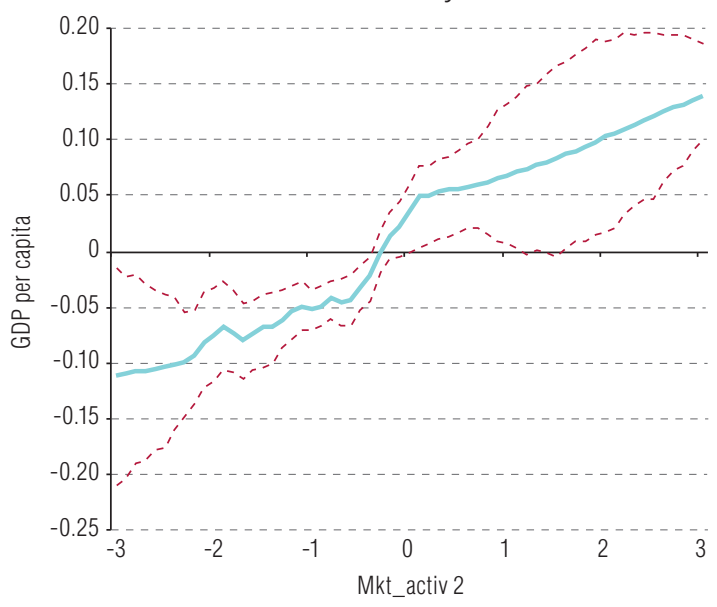

Source: Prepared by the authors.

Note: The solid line in each graph represents the estimated conditional expectation function value of the respective financial development variable. The dashed lines indicate 95\% confidence intervals of these estimated values. 
As described by Hamilton (2001), it is possible to calculate the value of any $z$ of interest from the values of $\vartheta=\left\{\beta_{0}, \beta_{1}, \ldots, \beta_{6}, \zeta, g_{1}, \sigma\right\}$, denoted as $z^{*}$. This calculation is the inference about the conditional expectation function value $\mu\left(z^{*}\right)$ when the explanatory variables assume the value represented by $z^{*}$ and when the parameters assume the value estimated by the model.

Thus, figure 1A plots $\hat{E}\left[\mu(\right.$ Dep_Vista $\left.) \mid Y_{T}\right]$ against Vari_dep, figure 1B $\hat{E}\left[\mu(\right.$ Fix_Dep $\left.) \mid Y_{T}\right]$ against Fix_dep, figure 1C $\hat{E}\left[\mu(\right.$ Tam_Merc $\left.) \mid Y_{T}\right]$ against Mkt_size, figure 1D $\hat{E}\left[\mu\left(M k t \_a c t i v 1\right) \mid Y_{T}\right]$ against Mkt_activ1 and figure $1 \mathrm{E} \hat{E}\left[\mu\left(\right.\right.$ Mkt_activ2) $\left.\mid Y_{T}\right]$ against Mkt_activ2. The dashed lines indicate $95 \%$ confidence intervals.

As shown in figures $1 \mathrm{~A}$ and 1B, Vari_dep begins to have significant effects on levels of state GDP per capita only once it reaches values of around -1 and, in the case of Fix_dep this occurs for values just below -1 . The effect is then positive and significant up to values of 0.5 . The gradient appears to even out before 0.5 for Vari_dep and 0.8 for Fix_dep, after which the effect is less significant, as evidenced by the smoother and more horizontal gradient, similar to that seen with values less than -1 .

Although the Mkt_size indicator (see figure 1C) follows a similar pattern, a more pronounced oscillation is observed for values from -1.6 to -0.4 . Although there are positive effects on state GDP per capita, they are less intense and are observed in a narrower band of Mkt_size, from -0.4 to 0.2.

Figure 1D shows an inverted $U$ pattern for the relationship between Mkt_activ1 and state GDP per capita, with a positive effect from around -1 to 0 . The effect then becomes negative, before turning positive again from around 0.5 onwards.

Finally, figure $1 \mathrm{E}$ charts a pattern that is qualitatively similar to those displayed in figures $1 \mathrm{~A}, 1 \mathrm{~B}$ and $1 \mathrm{C}$. When the value of Mkt_activ2 is between -2 and -0.5 , it has a positive but less significant effect on state GDP per capita. For values between -0.5 and 0.2 , a positive and significant effect is shown. Above this value, the gradient is gentler but still positive, reflecting the limit to which Mkt_activ2 can affect state GDP per capita.

In short, in the general context of the Brazilian reality, it is not possible to reject the existence of a non-linear relationship between financial development and economic growth, which becomes significant at intermediate and high values of financial development. In addition, when the proxy variable Mkt_activ1 is used, financial development reaches an inflection point, after which its effect on economic growth diminishes. According to Stengos and Liang (2004), one possible explanation for this inflection point is that when market activity reaches a certain level, financial intermediaries find it more difficult to finance lucrative projects and, consequently, end up financing less profitable projects. This results in a less efficient allocation of resources, which translates into lower economic growth.

From an empirical point of view, an initial hypothesis to explain the results obtained relates to the income levels of the Brazilian states. These results are similar to those found by Rioja and Valev (2004b), which classify countries into three different groups according to income level. In regions characterized by low income levels, most of which include very poor countries, increases in the level of financial development did not have statistically significant effects on economic growth. In middleincome regions, changes in the level of financial development are clearly the most effective at producing positive impacts on economic growth. Finally, in high-income regions, additional increases in the level of financial development have a positive effect on economic growth, albeit a small one.

Jalilian and Kirkpatrick (2005) also segment the effects of financial development on economic growth, indicating that financial development generates economic growth in low-income countries, but that this is not the case in high-income countries. Chen, Wu and Wen (2013) study the relationship between financial development and economic growth in Chinese provinces and produce results opposite to those of Jalilian and Kirkpatrick (2005), namely that financial development has a marked positive effect on economic growth in high-income provinces, but a pronounced negative effect on low-income provinces. According to Xu (2000), financial development has a negative impact on economic growth in low- and middle-income countries, but this does not occur in the high-income group of countries. Masten, Coricelli and Masten (2008) obtain similar results. 
A second hypothesis is linked to the level of financial development of the Brazilian states. In this regard, Minier (2003) argues that while financial development and economic growth are positively correlated in countries with a high level of financial development, this correlation does not seem to be maintained in countries where the level of financial development is low. Rioja and Valev (2004a) also argue that the relationship between financial development and economic growth varies according to the country's level of financial development. Specifically, the study revealed that financial development had a significant positive impact on economic growth in countries with medium and high levels of financial development, but a negligible effect in countries with low levels of financial development.

From the theoretical point of view, there are three perspectives that can explain the results. The first one of these was developed by Bencivenga, Smith and Starr (1995). According to the model developed by these authors, the transaction costs incurred in the financial intermediation process have a direct impact on economic growth. Economies with high transaction costs have at their disposal short-gestation capital production technologies. Thus, reductions in transactions costs can lead to the use of longer gestation capital production technologies that are more transaction-intensive, and to an increase in the interest rates on savings. However, such reductions do not necessarily result in a higher economic growth rate. This is because an increase in the liquidity of financial markets can cause a change in the composition of savings, which favours the holding of financial assets at the expense of the initiation of new capital investment. When this effect is large enough, improvements in the liquidity of financial markets will reduce the economic growth rate. Conversely, if sufficiently large reductions in transactions costs lead to the adoption of longer maturity capital investments of sufficiently greater productivity, then capital market improvements will enhance economic growth.

The second perspective relates to the work of Hung (2009), whose theoretical model demonstrates that financial development is capable of making loans viable for consumption and investment purposes. While investment loans promote economic growth, consumer loans have the opposite effect. Consequently, the effect of financial development on economic growth depends on the relative magnitude of these two different channels. The main result of the model reveals that the initial level of financial development plays a key role in determining the relative magnitudes of the two channels that affect economic growth, generating non-linear relationships between financial development and economic growth.

Lastly, the third aspect refers to the model of Deidda and Fattouh (2002), in which financial intermediation emerges and produces effects on economic growth only when the income of an economy reaches a certain level. According to Deidda, compared to self-financing, financial intermediaries allocate savings - net of transactions costs - to more productive investments. However, whenever firms operate a technology that is more productive and more capital-intensive than that available to households, the growth effect of financial development is ambiguous.

This result, which is in principle contradictory, can be explained by the fact that a more capital-intensive technology might pay a higher return to savers, even if the costs of financial intermediation are so high that production, and thus growth, fall relative to self-financing. Consequently, households might prefer to save through intermediaries instead of self-financing investments, even when consumption of resources by the financial sector yields a lower growth rate than would be the case in a self-financing situation.

The overlapping generations structure of the model is the key to the incentive mechanism for households. While the generation responsible for the transition enjoys a higher return on savings, the consequences of the possibly negative growth effect of financial development are felt by future generations of workers. Thus, if financial development reduces growth, these workers will receive lower incomes than they would have under self-financing.

Furthermore, whenever the process of financial development is sustainable, the credit market becomes more competitive and efficient over time and thus favours economic growth (Deidda, 2006). 


\section{Conclusions}

The relationship between financial development and economic growth has been extensively discussed in the literature, particularly as regards the supply-leading or demand-following debate. However, it is only in recent years that the supposedly linear functional form of this relationship has been questioned, with it being argued that it depends above all on a region's level of income and of financial development.

This study therefore attempts to analyse the functional form of the relationship in the case of Brazil, through a panel of the country's 27 states covering the period from 1995 to 2014. For this purpose, the flexible regression model developed by Hamilton (2001) was applied. This model consists of a parametric approach in which a functional form is not applied, a priori, to the relationship between the explanatory variable and the dependent variable. This methodology makes it possible to explicitly test whether the functional form found is linear or non-linear.

The results obtained show that there is a positive non-linear relationship between financial development and economic growth for the five financial development indicators used. The overall impact of financial development on economic growth was shown to be positive and significant for intermediate to high levels of financial development. The exception was the financial market activity indicator comprising the ratio of credit transactions to state GDP, which revealed a decreasing effect on economic growth under high levels of financial development, evidenced by an inverted U-shaped relationship, similar to the results produced by Stengos and Liang (2004).

One possible explanation for this inflection point is that when market activity reaches a certain level, financial intermediaries find it more difficult to finance lucrative projects and, consequently, end up financing less profitable projects. This results in a less efficient allocation of resources, which translates into lower economic growth.

In light of the above, it appears that regional inequalities between Brazilian states end up influencing the effect financial development has on economic growth, since two well-defined forms of the relationship between these variables have been identified. In one, financial development is limited and has little effect on economic growth, while in the other, the level of financial development is medium or high and has a positive and significant impact on economic growth.

In this regard, the results support the argument that policies aimed at promoting financial development cannot be implemented homogeneously throughout the national territory, since they will have different effects on economic growth. In other words, different regions cannot be treated as if they were identical.

This indicates a need to prioritize policies to increase income through financial development in regions where such development is limited, given that, when intermediate or high levels of financial development are reached, it is these regions that reap the greatest rewards in terms of economic growth. Moreover, fostering financial development policies in regions where such development is already high could have an adverse impact, negatively affecting economic growth.

The main limitations of the study are that the proxy variables for financial development only capture the banking sector, neglecting the portion of financial development related to the capital market, and they only cover depository units, excluding other financial intermediaries such as development agencies; savings and loan associations; exchange bureaus; development banks; investment banks; mortgage companies; central credit unions; credit institutions; credit, financing and investment firms; building societies; and microfinance firms.

However, if the analysis were carried out in terms of volume of resources and not of omitted agents, this distortion would be greater, since it excludes, for example, investment banks and the capital market which, according to Assaf Neto (2015), are the main drivers of medium- and long-term credit in 
the market and responsible for providing the economy with permanent resources by extending loans to those agents lacking resources for investment in working capital and fixed capital. Nevertheless, this limitation does not appear to have a qualitative effect on the results, since in the theoretical and empirical literature financial agents are treated in a homogeneous manner when defining the term "financial development". As Levine (1997) notes, since they play a key role in the financial system of an economy, financial agents will promote "financial development" by reducing transaction and information costs between savers and investors.

Another limitation of the study is that the empirical model specification used accepts the results presented to date regarding the one-way causality of financial development on economic growth in Brazil (Arraes and Teles (2000), Monte and Távora Júnior (2000), Matos (2002), Marques Jr. and Porto Jr. (2004), Rocha and Nakane (2007) and Missio, Jayme Jr. and Oliveira (2010)). In this regard, the non-linear relationships identified presuppose unilateral causality between the variables.

This article and previous research on the subject provide some guidelines for future studies. The first is the need for more in-depth regional studies, since financial development is inextricably linked to institutional and economic factors that are specific to each region. The second is that, while most studies focus on determining the impact of financial development on economic growth, little attention has been paid to the factors that may or may not bring about financial development. Analysis of how government intervention and sector-specific policies of liberalization or financial repression affect financial development would fill a gap in the literature. Lastly, new proxies must be developed to capture other aspects of financial development in order to shed light on other points of view and give new impetus to research on the subject.

\section{Bibliography}

Arraes, R. and V. Teles (2000), "Endogeneidade e exogeneidade do crescimento econômico: uma análise comparativa entre Nordeste, Brasil e países selecionados", Revista Econômica do Nordeste, No. 31, Special Issue, Fortaleza, Technical Office for Economic Studies of the Northeast (ETENE).

Assaf Neto, A. (2015), Mercado financeiro, São Paulo, Atlas.

Barro, R. (1991), "Economic growth in a cross section of countries", Quarterly Journal of Economics, vol. 106, No. 2, Oxford, Oxford University Press.

Bencivenga, V. and B. Smith (1991), "Financial intermediation and endogenous growth", Review of Economic Studies, vol. 58, No. 2, Oxford, Oxford University Press.

Bencivenga, V., B. Smith and R. Starr (1996), "Equity markets, transaction costs, and capital accumulation: an illustration", World Bank Economic Review, vol. 10, No. 2, Washington, D.C., World Bank.

(1995), "Transactions costs, technological choice, and endogenous growth", Journal of Economic Theory, vol. 67, No. 1, Amsterdam, Elsevier.

Blackburn, K. and V. Hung (1998), "A theory of growth, financial development and trade", Economica, vol. 65, No. 257, Hoboken, Wiley.

Chandavarkar, A. (1992), "Of finance and development: neglected and unsettled questions", World Development, vol. 20, vol. 1, Amsterdam, Elsevier.

Chen, K., L. Wu and J. Wen. (2013), "The relationship between finance and growth in China", Global Finance Journal, vol. 12, No. 1, Amsterdam, Elsevier.

Cintra, M. (2009), "Crédito público e desenvolvimento econômico: a experiência brasileira", Ensaios sobre Economia Financeira, F. Ferreira and B. Meirelles (orgs.), Rio de Janeiro, Brazilian National Bank for Economic and Social Development (BNDES).

Crocco, M., F. Santos and P. Amaral (2009), "The spatial structure of the financial development in Brazil", Texto para Discussão CEDEPLAR-UFMG, No. 361, Belo Horizonte, Federal University of Minas Gerais.

Dahl, C. and G. González-Rivera (2003), "Testing for neglected non-linearity in regression models based on the theory of random fields", Journal of Econometrics, vol. 114, No. 1, Amsterdam, Elsevier. 
De Gregorio, J. and P. Guidotti (1995), "Financial development and economic growth”, World Development, vol. 23, No. 3, Amsterdam, Elsevier.

Deidda, L. (2006), "Interaction between economic and financial development", Journal of Monetary Economics, vol. 53, No. 2, Amsterdam, Elsevier.

Deidda, L. and B. Fattouh (2002), "Non-linearity between finance and growth", Economics Letters, vol. 74, No. 3, Amsterdam, Elsevier.

Goldsmith, R. (1969), Financial Structure and Development, New Haven, Yale University Press.

Greenwood, J. and B. Jovanovic (1990), "Financial development, growth, and the distribution of income", Journal of Political Economy, vol. 98, No. 5, Chicago, Chicago University Press.

Gurley, J. and E. Shaw (1955), "Financial aspects of economic development", The American Economic Review, vol. 45.

Hamilton, J. (2001), "A parametric approach to flexible nonlinear inference", Econometrica, vol. 69, No. 3, Hoboken, Wiley.

Hung, F. (2009), "Explaining the nonlinear effects of financial development on economic growth", Journal of Economics, vol. 97, No. 1, New York, Springer.

Jalilian, H. and C. Kirkpatrick (2005), "Does financial development contribute to poverty reduction?", Journal of Development Studies, vol. 41, No. 4, Abingdon, Taylor \& Francis.

Johnston, J. and J. Dinardo (1997), Métodos Econométricos, Lisbon, McGraw-Hill.

King, R. and R. Levine (1993a), "Finance and growth: Schumpeter might be right", Quarterly Journal of Economics, vol. 108, No. 3, Oxford, Oxford University Press.

(1993b), "Finance, entrepreneurship, and growth: theory and evidence", Journal of Monetary Economics, vol. 32, No. 3, Amsterdam, Elsevier.

Kuznets, S. (1955), "Economic growth and income inequality", The American Economic Review, vol. 45, No. 1, Nashville, American Economic Association.

Lawrence, P. (2006), "Finance and development: why should causation matter?", Journal of International Development, vol. 18, No. 7, Hoboken, Wiley.

Levine, R. (1998), "The legal environment, banks, and long-run economic growth", Journal of Money, Credit and Banking, vol. 30, No. 3, Ohio, Ohio State University Press.

(1997), "Financial development and economic growth: views and agenda", Journal of Economic Literature, vol. 35, Nashville, American Economic Association.

Lucas Jr., R. (1988), "On the mechanics of economic development”, Journal of Monetary Economics, vol. 22, No. 1, Amsterdam, Elsevier.

Marques Jr., T. and S. Porto Jr. (2004), "Desenvolvimento financeiro e crescimento econômico no Brasil - Uma avaliação econométrica”, Trabalho para Discussão PPGE/UFRGS, No. 11, Porto Alegre, Federal University of Rio Grande do Sul.

Masten, A., F. Coricelli and I. Masten (2008), "Non-linear growth effects of financial development: does financial integration matter?", Journal of International Money and Finance, vol. 27, No. 2, Amsterdam, Elsevier.

Matos, O. de (2002), "Desenvolvimento do sistema financeiro e crescimento econômico no Brasil: evidências de causalidade", Trabalhos para Discussão, No. 49, Brasilia, Central Bank of Brazil.

McKinnon, R. (1973), Money and Capital in Economic Development, Washington, D.C., The Brookings Institution.

Minier, J. (2003), "Are small stock markets different?", Journal of Monetary Economics, vol. 50, No. 7 , Amsterdam, Elsevier.

Missio, F., F. Jayme Jr. and A. Oliveira (2010), "Desenvolvimento financeiro e crescimento econômico: teoria e evidência empírica para os estados brasileiros (1995-2004)", Textos para Discussão CEDEPLARUFMG, No. 379, Belo Horizonte, Federal University of Minas Gerais [online] http://www.cedeplar.ufmg. br/pesquisas/td/TD 379.pdf.

Modenesi, A. (2010), "Política monetária no Brasil pós plano real (1995-2008): um breve retrospecto", Economia \& Tecnologia, vol. 21, Curitiba, Federal University of Parana.

Monte, P. and J. Távora Júnior (2000), "Fontes de financiamento do Nordeste e o produto interno bruto da região", Revista Econômica do Nordeste, vol. 31, Special Issue, Fortaleza, Technical Office for Economic Studies of the Northeast (ETENE).

Morais, J. (2008), "Programas especiais de crédito para micro, pequenas e médias empresas: BNDES, PGER e fundos constitucionais de financiamento", Políticas de Incentivo à Inovação Tecnológica no Brasil, J. de Negri and L. Kubota. (orgs.), Brasilia, Institute of Applied Economic Research (IPEA). 
Murinde, V. (1996), "Financial markets and endogenous growth: an econometric analysis for Pacific Basin countries", Financial Development and Economic Growth: Theory and Experiences from Developing Countries, N. Hermes and R. Lensink (eds.), Abingdon, Routledge.

Murinde, V. and F. Eng (1994a), "Financial development and economic growth in Singapore: demand following or supply leading?", Applied Financial Economics, vol. 4, No. 6, Abingdon, Taylor \& Francis.

_ (1994b), "Financial restructuring and economic growth in Singapore", Savings and Development, vol. 18, No. 2, Giordano Dell'Amore Foundation.

Pagano, M. (1993), "Financial markets and growth: an overview", European Economic Review, vol. 37, No. 2-3, Amsterdam, Elsevier.

Patrick, H. (1966), "Financial development and economic growth in underdeveloped countries", Economic Development and Cultural Change, vol. 14, No. 2, Chicago, University of Chicago Press.

Rioja, F. and N. Valev (2004a), "Does one size fit all?: A reexamination of the finance and growth relationship", Journal of Development Economics, vol. 74, No. 2, Amsterdam, Elsevier. (2004b), "Finance and the sources of growth at various stages of economic development", Economic Inquiry, vol. 42, No. 1, Hoboken, Wiley.

Robinson, J. (1952), The Rate of Interest and Other Essays, London, Macmillan.

Rocha, B. and M. Nakane (2007), "Sistema financeiro e desenvolvimento econômico: evidências de causalidade em um painel para o Brasil", Proceedings of the 35th Brazilian Economics Meeting, Pernambuco, Brazilian Association of Graduate Programs in Economics (ANPEC).

Rousseau, L. and P. Wachtel (2001), "Inflation, financial development, and growth", Economic Theory, Dynamics and Markets: Essays in Honor of Ryuzo Sato, T. Negishi, R. Ramachandran and K. Mino (eds.), Boston, Kluwer.

Romer, P. (1990), "Endogenous technological change”, Journal of Political Economy, vol. 98, No. 5, Chicago, Chicago University Press.

(1986), "Increasing returns and long-run growth", Journal of Political Economy, vol. 94, No. 5, Chicago, Chicago University Press.

Roubini, N. and X. Sala-i-Martin (1992), "Financial repression and economic growth", Journal of Development Economics, vol. 39, No. 1, Amsterdam, Elsevier.

Saint-Paul, G. (1992), "Technological choice, financial markets and economic development", European Economic Review, vol. 36, No. 4, Amsterdam, Elsevier.

Schumpeter, J. (1934), The Theory of Economic Development: An Inquiry into Profits, Capital, Credit, Interest, and the Business Cycle, Cambridge, Harvard University Press.

Shaw, E. (1973), Financial Deepening in Economic Development, New York, Oxford University Press.

Shen, C. and others (2011), "Roles played by financial development in economic growth: application of the flexible regression model", Empirical Economics, vol. 41, No. 1, Berlin, Springer.

Singh, A. and B. Weisse (1998), "Emerging stock markets, portfolio capital flows and long-term economic growth: micro and macroeconomic perspectives", World Development, vol. 26, No. 4, Amsterdam, Elsevier.

Stengos, T. and Z. Liang (2004), "Financial intermediation and economic growth: a semiparametric approach", C. Diebolt and C. Kyrtsou (eds.), New Trends in Macroeconomics, Berlin, Springer.

Stern, N. (1989), "The economics of development: a survey", The Economic Journal, vol. 99, No. 397, Hoboken, Wiley.

Stiglitz, J. (1994), "The role of the state in financial markets", Proceedings of The World Bank Conference on Development Economics, Washington D.C., World Bank.

Stulz, R. (2000), "Does financial structure matter for economic growth? A corporate finance perspective" [online] http://citeseerx.ist.psu.edu/viewdoc/download?doi=10.1.1.18.9116\&rep=rep1\&type=pdf.

Wooldridge, J. (2001), Econometric Analysis of Cross Section and Panel Data, Cambridge, MIT Press.

Xu, Z. (2000), "Financial development, investment, and economic growth", Economic Inquiry, vol. 38, No. 2, Hoboken, Wiley. 